\title{
Pengembangan Soal Matematika Tipe PISA Menggunakan Konteks Wisata Banyumas dan Cilacap
}

\author{
M. Noviarsyah Dasaprawira \\ Universitas Nahdlatul Ulama Al Ghazali Cilaca \\ *viarprawira10@gmail.com
}

\begin{tabular}{|l|l|l|l|}
\hline Received: 02-12-2020 & Revised: $18-05-2021$ & Accepted: $30-05-2021$ & Published: 06-06-2021 \\
\hline
\end{tabular}

\begin{abstract}
ABSTRAK
Penelitian ini bertujuan untuk menghasilkan soal matematika tipe PISA menggunakan konteks wisata banyumas dan cilacap yang valid dan praktis. Metode penelitian ini menggunakan metode penelitian design research dengan tipe development study. Penelitian ini terdiri dari tahapan utama yaitu prelimininary terdiri dari persiapan dan desain sedangkan formative Evaluation terdiri dari self evaluation, expert reviews, one-to-one, dan field Test. Penelitian ini menghasilkan 7 unit soal yang valid dan praktis dan terdapat 12 soal yang telah dikembangkan. Kriteria valid pada soal ini dilihat dari aspek konten, konstruk, dan bahasa, sedangkan aspek kepraktisan dilihat dari hasil small group dimana soal dengan konteks yang dikenali siswa. Sehingga guru memilki refrensi soal untuk digunakan dalam persiapan AKM.
\end{abstract}

Kata Kunci : Pendidikan, PISA, AKM

\section{ABSTRACT}

This study aims to produce valid and practical mathematical problems using Banyumas and Cilacap tourism contexts. The research method used was a design research research method with a development study type. The research consists of the main stages consisting of preparation and design while the formative evaluation consists of self-evaluation, expert review, one-to-one, and field tests. This study resulted in 7 units of valid and practical questions and there were 12 questions that had been developed. The valid criteria in this question are seen from the aspects of content, construct, and language, while the practical aspect is seen from the results of small groups where the questions are with a context that is recognized by students. So that the teacher has a question reference to use in preparation for the AKM.

Keywords: education, PISA, AKM.

\section{PENDAHULUAN}

Programme for nternational Student Assessment (PISA) merupakan sebuah organisasi yang memiliki tugas dan tujuan untuk menilai kemampuan siswa di seluruh dunia dan PISA bagian dari Organization for Economic Coorperation and Development (OECD). PISA melakukan penilaian kepada siswa di seluruh duia dengan kriteria umur 15 tahun pada kemampuan pengetahuan maupun keterampilan membaca, matematika dan sains dikehidupan nyata (OECD, 2016).

PISA diadakan setiap 3 tahun sekali, indonesia merupakan salah satu negera yang mengikuti program OECD untuk menilai kemampuan siswa indonesia yang memiliki umur 15 tahun. Indonesia sejak tahun 2000 hingga tahun 2018 terus menerus mengikuti 
penilaian tersebut alhasil kemampuan siswa indonesia tergolong rendah dibandingkan dengan negara negara tetangga seperti singapura/ senada dengan Dasaprawira, N, N \& Aspriyani., R. (2020) menyatakan bahwa kemampuan literasi matematika siswa tergolong rendah terlihat pada hasil PISA tahun 2012 dan tahun 2015. Rendahnya kemampuan siswa indonesia ini terlihat pada kemampuan literasi (Rahmawati, 2018; Septian, Komala, \& Komara, 2019). Menurut Novita, Zulkardi, \& Hartono (2012) bahwa siswa indonesia belum terbiasa dengan soal-soal konstekstual seperti pada soal PISA yang utamanya soal level tinggi baik proses pembelajaran maupun evaluasinya. Sedangkan menurut Suryadinata (2020), siswa indonesia pada umumnya kurang terlatih dala menyelesaikan soal soal dengan karakteristik seperti soal soal TIMS dan PISA.

Hal ini lah yang mendasari kurikulum 2013 terlahir dimana sebelumnya kurikulum KTSP. Selama ini penilaian atas ketercapaian siswa indonesia dilihat pada hasil ujian Nasional untuk siswa kelas IX Sekolah Menengah Pertama, ataupun siswa kelas XII Sekolah Menegah Atas. Terkait hal tersebut Menteri Pendidikan dan Kebudayaan bapak Nadiem Makarim mengatakan bahwa Ujian Nasional dihapuskan dan digantikan dengan Asessmen Kompetensi Minimum (AKM).

Kehadiran AKM menggantiakn UN berlandaskan hasil PISA indonesia yang belum mengalami perbaikan, penilaian AKM ini mengukur ketercapaian dari hasil belajar kognitif literasi dan numerasi. (kompas.com, 2020). Soal-soal yang diterapkan pada AKM mengadopsi dari soal soal PISA, sehingga guru, dosen ataupun peneliti harus menyiapkan bahan ajar ataupun soal soal yang berkarekter soal PISA. Berikut ini peta jalan penelitian ini :

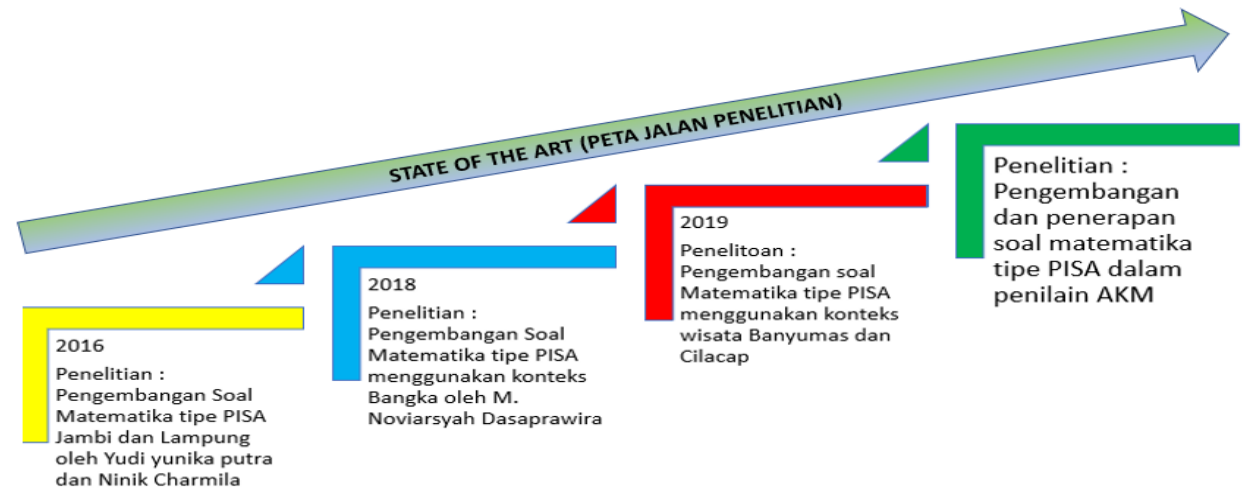

Gambar 1. Peta Jalan Penelitian

Peneliti membuat soal PISA menggunakan konteks wisata banyumas dan cilacap berharap soal yang dikembangkan bisa digunakan oleh guru untuk diberikan siswa membantu dalam membiasakan siswa menyelesaika soal soal yang berlevel tinggi. Seperti 
yang dikatakan oleh Dasaprawira, M.,N, Zulkardi, \& Susanti, E. (2019) bahwa siswa indonesia belum terbiasa menyelesaikan soal soal PISA. Berdasarkan uraian di atas, peneliti bertujuan untuk menghasilkan soal matematika tipe PISA menggunakan konteks wisata Banyumas dan Cilacap yang valid dan praktis.

\section{METODE PENELITIAN}

Metode dalam penelitian ini menggunakan metode penelitian design research dengan tipe Development Study. Penelitian ini terdiri dari tahapan utama yaitu prelimininary dan formative Evaluation. Menurut Tessmer (1993), dan Zulkardi (2006) tahapan preliminary terdiri dari persiapan beruapa analisis dan design, sedangkan tahapan formative evaluation terdiri dari self evaluation, expert reviews, one-to-one, small group dan field test. Berikut alur desain formative evaluation.

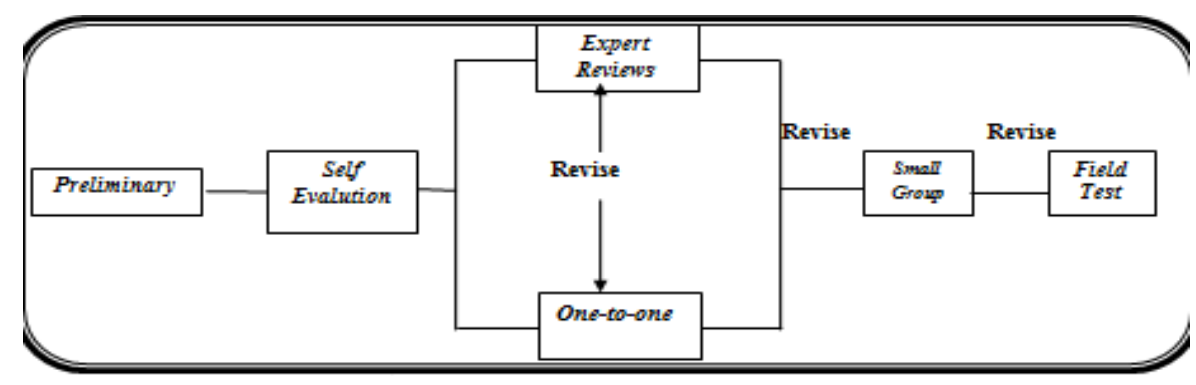

Gambar 2. Desain Formative Evaluation

Subjek peneliti ini adlaah siswa kelas IX SMP Negeri 1 Majenang Kabupaten Cilacap, penelitian ini diadakan pada waktu semester ganjil tau ajaran 2020-2021. Rancangan penelitian pada tahapan preliminary melakukan persiapan, berupa analisis dan design. Tahapan analisis melakukan analisis kurikulum di sekolah sebagai lokasi objek penelitian serta buku pegangan guru.persiapan yang lain ialah mengatur waktu penelitian kepada pihak guru dan sekolah. Selanjutnya penelitia melakukan pendesainan kisi kisi dan soal matematika tipe PISA berkonteks wisata banyumas dan cilacap. Tahap Formative Evaluation yaitu Self Evaluation , pada tahap ini dilakukan penilaian oleh diri sendiri yang telah dibuat oleh peneliti terhadap hasil desain soal-soal model PISA. Kemudian Expert Review, pada tahap ini desain soal yang telah dibuat oleh peneliti kemudian divaludi oleh pakar dimana produk yang telah dibuat dilihat, dinilai, dan dievaluasi. Uji validitas yang dilakukan adalah uji validitas konten, konstruk, dan bahasa. Tanggapan dan saran dari validator di tulis pada lembar validasi yang digunakan untuk merevisi desain soal dan untuk menyatakan bahwa perangkat pembelajaran tersebut telah valid. Serta One-to-one, 
pada tahap one-to-one ini, peneliti meminta 3 orang siswa serta komentar yang didapat akan digunakan untuk merevisi soal model PISA yang telah dibuat oleh peneliti. Tahap Small Group, hasil dari revisi dan komentar expert review dan one-to- one dinamakan prototype 2 yang dijadikan dasar untuk mendesain soal pada tahap selanjutnya. Small group diujicobakan dengan 6 orang siswa. Desain soal ini diujicobakan pada small group dimana siswa tersebut diminta untuk memberikan tanggapan terhadap soal-soal model PISA yang diujikan. Berdasarkan hasil tes dan tanggapan siswa inilah soal direvisi dan diperbaiki lagi. Hasil dari revisi soal dari tahap small group dinaakan prototype 3 yang akan diujicobakan pada tahap field test. Hasil dari prototype 3 diujicobakan pada field test di SMP Negeri 1 Majenang. Tahap field test bertujuan untuk mendapatkan soal matematika tipe PISA yang valid dan praktis serta mengetahui efek potensial soal yang dikembangkan terhadap literasi matematika siswa

Adapun Prosedur Pengumpulan Data yaitu dokumen yang digunakan pada tahap self evaluation adalah kurikulum 2013 SMP, framework PISA, dan mendesain perangkat soal PISA menggunakan karakteristik konstruk, konten, dan bahasa diperoleh prototype awal. Walk through dilakukan dengan pakar pada tahap expert review. Hasil dari walk through digunakan untuk merivisi prototype awal yang dilaksanakan bersamaan dengan one-to-one untuk mendapatkan prototype ke dua.

Tes diberikan tes soal matematika model PISA yang telah dikembangkan sebelumnya terhadap 3 orang siswa berkemampuan tinggi, sedang, dan rendah SMP kelas IX. Wawancara dilakukan kepada siswa ketika mengerjakan soal model PISA pada tahap one-to-one . Hasil wawancara akan digunakan sebagai bahan revisi pada prototype awal dan melihat kejelasan soal. Observasi dilaksanakan kepada siswa ketika mengerjakan soal matematika model PISA pada tahap one-to-one dimana observasi yang dilakukan untuk mengetahui kesulitan-kesulitan siswa dalam mengerjakan soal dan mengetahui kepraktisan soal.

Teknik Analisis Data yaitu analisis dokumen dimana peneliti menganalisis sendiri perangkat soal prototype pertama yang sudah dihasilkan untuk mengetahui apakah perangkat soal yang dikembangkan sudah sesuai dengan framework PISA, kurikulum 2013 SMP, serta kemampuan literasi matematis siswa. Analisis Walk through peneliti melakukan analisis dengan cara merevisi berdasarkan walk through sehingga soal yang dibuat peneliti diperoleh soal yang valid.

Analisis Wawancara dengan mengamati kesulitan dan temuan pengerjaan siswa dimana hasil ini digunakan untuk merevisi soal-soal yang dibuat peneliti. Analisis 
Observasi juga digunakan untuk melihat kendala siswa dalam mengerjakan soal matematika model PISA yang telah dikembangkan guna merevisi soal yang telah dibuat peneliti. Kemudian tes soal yang telah dikembangkan untuk melihat kevalidan dan kepraktisan terhadap soal yang dikembangkan.

\section{HASIL DAN PEMBAHASAN}

Proses pengembangan soal dalam peneilitian ini menggunakan metode eneltiian design research dengan tipe development study. Pengembangan soal matematika tipe PISA telah melakukan beberapa tahapan sebelumnya yaitu persiapan berupa analisis dan desain. Tahapan preliminary terdiri dari analisis yang terdiri dari analisis siswa, analisis kurikulum dan analisis soal PISA. Pada tahapan analisis ini peneliti menggunakan siswa SMP N 1 Majenang kelas IX, selanjutnya peneliti mengidentifikasi siswa yang akan berperan dalam tahapan one-to-one, small group dan field tes yang direkomendasikan oleh guru matematika. Masing masing setiap kelompok ujicoba ditahapan one-to-one menggunakan 3 orang siswa dengan kriteria tinggi, sedang, dan rendah, sedangkan small group menggunkan 2 kelompok dimana masing-masing kelompok terdiri 3 siswa dengan kriteria yang berbeda yaitu tinggi, sedang, dan rendah.. pada tahapan field test menggunakan siswa 1 kelas dengan jumlah siswa sebanyak 30 orang dengan kemampuan yang heterogen dengan siswa yang berbeda dari tahapan one-to-one dan small group. Tahapan desain dihasilkan 7 buah konteks dengan rincian 2 soal dengan konteks permaian konsentrasi, 1 soal dengan konteks sebuah bangun belah ketupat, 3 soal dengan konteks pos penjaga dengan bentuk klasik jawa, 1 soal dengan konteks motif batik, 2 soal dengan konteks tangga awalan flyngfox, 2 soal dengan konteks kebudayaan cilacap gunungan yutuk, dan 1 soal dengan konteks pintu masuk benteng pendem.

Selanjutnya ialah self evaluation dimana peneliti menelaah kembali prototipe yang sebelumnya telah didesign, serta peneliti meminta masukan kepada salah satu guru SMP N 1 Majenang untuk melihat bahasa yang digunakan apakah membuat siswa mengalami kebingungan ataupun siswa berfikir yang lai. Hasil dari review terhadap guru SMP N 1 Majenang, bahwa bahasan yang digunakan sudah baik tidak menimbulkan makna ganda, tetapi beberapa kata diperbaiki yang lebih mudah siswa memahami selanjutnya hasil ini disebut dengan prototype 1.

Pada tahapan selanjutnya untuk mendapatkan prototype 2 peneliti memberikan kepada 2 pakar yaitu Dr. Rully Charitas Indra Pramana dan Yudi Yunika Putra, M.Pd. pada tahapan expert review dan one to one. Peneliti memberikan prototyipe 1 kepada pakar 
yaitu Dr. Rully Charitas Indra Pramana dan Yudi Yunika Putra, M.Pd untuk memvalidasi berupa aspek konten, konstruks, dan bahas. Terkait hasil validasi dari pakar bahwa aspek konten soal yang dikembangkan perlu diperbaiki dalam hal level soal yang dikembangkan, pada aspek konstruks beberapa gambar/konteks pada soal dikembakan harus lebih jelas sehingga tidak membuat siswa mengalami bingung dan mengalami kesulitan membaca gambar yang kurang jelas. Sedangkan pada aspek bahasa menurut kedua pakar masih ada kata-kata yamg ambigu. Maka dari hasil validasi oleh pakar, peneliti melakukan perbaikan terdapat soal soal yang mengalami koreksi oleh pakar tersebut.berikut ini salah satu konteks yang mengalami perbaikan :
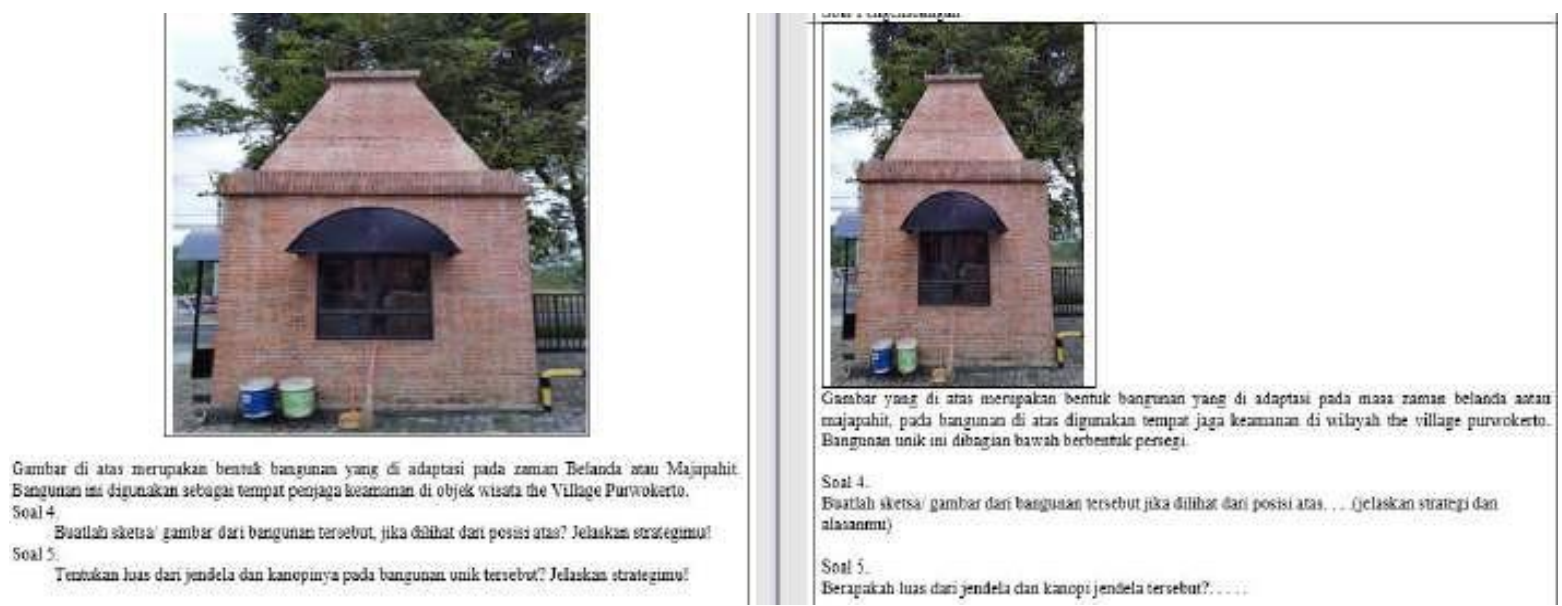

Gambar 3.Kiri sebelum Revisi dan Kanan sesudah Revisi

Selama proses validasi kepada pakar, peneliti melakukan tahapan one-to-one . Tahapan ini menggunakan 3 orang siswa yang memiliki kemampuan yang berbeda yaitu tinggi, sedang, dan rendah.hasil dari tahapan one-to one ini bahwa berkomentar cukup baik terhadap soal yang dikembangkan akan tetapi ada beberapa soal yang membuat siswa mengalami kesulitan yaitu berupa soal dengan gambar yang kurang jelas.terkait hal tersebut peneliti mengambil kesimpulan untuk melakukan erbaikan terhadap konteks soal yang dinilai kurang jelas. Dari hasil validasi terhadap kedua pakar dan siswa maka di hasilkan prototipe 2 .

Selanjutnya pada tahapan small group, peneliti telah mendapatkan prototipe kedua yang valid dinilai oleh pakar dan siswa. Peneliti memberikan prototipe 2 kepada 2 kelompok siswa, dengan masing masing kelompok tersebut terdiri dari 3 orang siswa dengan kriteri yang berbeda yaitu tinggi, sedang, dan rendah. Tahapan small group ini bertujuan untuk melihat prototype ini sudah praktis atau bisa digunakan atau tidak, dan tahapan ini melihat apakah siswa memahami maksud soal yang diberikan baik secara informasi , gambar ataupun angka. Pada saat siswa mulai mengerjakan soal baik secara 
individu ataupun kelompok, peneliti melihat siswa mengalami perdebatan cara/strategi apa yang lebih tepat digunakan dalam menjawab pertanyaan yang disediakan terkait hal tersebut peneliti melihat itu baik dan bagus mengenai diskusi yang siswa lakukan. Sehingga peneliti tidak menemukan maslaah yang begitu besar pada siswa dalam memahami soal yang telah dikembangkan, sehingga semua soal yang dikembangkan tidak mengalami revisi dan dapat digunakan pada tahapan selanjutya. Pada tahapan selanjutnya ialah field test menggunakan prototipe 3 yang telah praktis dilihat dari tahapan small grop.

Dari hasil pengujian prototype kepada pakar, siswa one-to-one dan siswa small group di dapatkan soal matematika tipe PISA menggunakan konteks banyumas dan cilacap yang valid dan praktis. Berikut ini contoh soal yang telah dikembangkan, valid dan praktis:

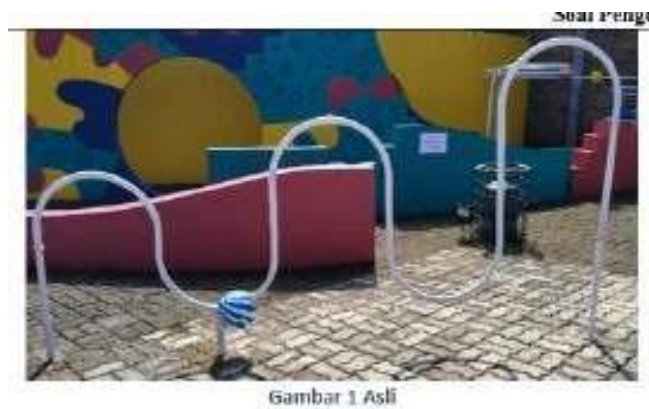

Gambar 1 Asti

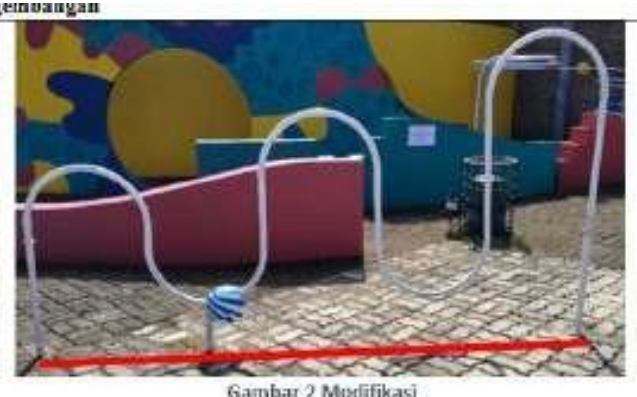

Gambar 2 Modifikas

Berikut ini adalah sebuah permainan yang menqutamakan konsettrasi. Biasanva, permainan seperti ini terdapat di tempat wigata, salah satmena di The Village Purwokerto.

Soal 1

Hitunglah parjang besi dalam permainan ini, seperti can pak pada Gambar 17 Jelaskan strategimu!

Soal 2

Pada Gambar 2 , bitanglab luas bangwo tak becataran teracbut?

Jelaskan strategium!

Soat 3 .

Tertukan jumelah beetuk belahketipat yang terdapat pada gambar di atas? Selaujutnya, hitunglah jarak antara pangkal bentuk belahketupat pertana bingga belahkerupat terakhir?

Jelaskan strategimu!

Gambar 4. Contoh Soal Konteks Banyumas dan Cilacap 


\section{KESIMPULAN}

Penelitian ini menghasilkan seperangkat soal matematika tipe PISA menggunakan konteks wisata banyumas dan cilacap, terdiri dari 7 unit dengan sebaran 12 soal berkonteks yang valid dan prakts. Kriteria valid pada soal ini dilihat dari segi konten/isi (soal sesuai domain literasi matematika PISa untuk konten, konteks, dan kemampuan proses), konstruk (soal sesuai dengan karakteristik levelsoal PISA dan kemampuan siswa kelas IX), dan bahasa (soal menggunakan bahasa yang sesuai dengan EYD dan dapat dipahami siswa) pada tahap expert reviews dan oe-to-one . sedangkan kriteria kepraktisan soal dilihat darihasil small group dimana soal dengan konteks yang dikenali siswa tersebut dapat diapahami siswa dan diterapkan daalam pembelajaran.

\section{REFERENSI}

Akker, V.D.,. (1999). Principles and Methode of development Research London. Dlm. Van Den Akker, J., Branch, R.M., Gustafson, K., Nieveen, N., \& Plomp, T. (pyt)”. Design approaches and tools in ducational and training. Dordrecht: Kluwer Academic Publisher.

Afriyanti, I., Wardono., \& Kartono. (2018). Pengembangan Literasi Matematika Mengacu PISA melalui Pembelajaran Abad ke-21 Berbasis Teknologi.

Dasaprawira, M. N., Zulkardi., \& Susanti, E. (2019). Developing Mathematics Wuestions of PISA Type Using Bangka Context. Journal Mathematics Education. 10(2). 303-314.

Dasaprawira, M. N., \& Aspriyani, R. (2020). Pengembangan soal Matematika tipe PISA menggunakan konteks Puri Tri Agung. Epsilon. Vol. 2 No. 1. 35-42

Fajriyah, M., Putri, R.I.I., \& Zulkardi (2017). Dayung Context in Fraction. Proceedings of the 5th SEA-DR (South East Asia Development Research) International Conference 2017 (pp. 1-6). Banjarmasin: Universitas Lambung Mangkurat. https://doi.org/seadric17.2017 .1

Jurnaidi dan Zulkardi. (2013). Pengembangan Soal Model Pisa Pada Konten Change and Relationship Untuk Mengetahui Kemampuan Penalaran Matematis Siswa Sekolah Menengah Pertama. JURNAL PENDIDIKAN MATEMATIKA Volume 7 No.2 Juli 2013 . hal 37-54. FKIP Universitas Sriwijaya.

Kemendikbud. (2013). Pengembangan Kurikulum 2013. Jakarta: Kementerian Pendidikan dan Kebudayaan.

Ninik, C., Zulkardi., \& Darmawijoyo. (2016). Pengembangan Soal Matematika Model PISA menggunakan Konteks Jambi. Jurnal Penelitian dan Evaluasi Pendidikan. 20(2), (198207).

Novita, R., Zulkardi., \& Hartono, Y. (2012). Exploring primary students's problem- solving ability by doing tasks like PISA's questio. IndoMS. J.M.E, 3(2), 133-150

OECD. (2009a). Learning Mathematics for Life: A Perspective from PISA. Paris: OECD Publishing.

OECD. (2009b). Learning Mathematics for Life: A Perspective from PISA. Paris: OECD. Publishing.

OECD. (2010). PISA 2012 assessment and analytical framework: mathematics, reading, science, problem solving and financial literacy. German: OECD Publishing.

OECD. (2016). PISA 2015 Assessment and Analytical Frameworks : Science, Reading, Mathematic and Financial Literacy. PISA, Paris : OECD Publishing. 
OECD (2018), PISA 2018 Draft-Framework. New York : Columbia University

Rahmawati, N. I. (2018). Pemanfaatan ICT dalam Meningkatkan Kemampuan Literasi Matematika. PRISMA, 1, 381-387

Stacey, K. (2014). The PISA view of mathematical literacy in Indonesia.Journal on Mathematics Education, 2(02), 95-126.

Septian, A., Komala, E., \& Komara, K. A. (2019). Pembelajaran dengan Model Creative Problem Solving (CPS) untuk Meningkatkan Kemampuan Berpikir Kreatif Matematis Siswa. Jurnal Prisma Universitas Suryakancana

Suryadinata, N. (2020). Membiasakan Siswa dngan Soal Matematika PISA. Seminar Nasional Pendidikan ke-3 FKIP universitas Lampug 2020 .

Tessmer, M. (1998). Planning and conducting formative evaluations: improving the quality of education and training. London: Kogan Page

Zulkardi (2002) Zulkardi, (2002). Developing a learning on realistic mathematics education for Indonesian students teachers. Doctoral dissertation. Enschede: University of Twente, Enschede. The Nederland. (Online). Tersedia: http://doc.utwente.nl/58718/1/thesis_Zulkardi.pdf. diakses 7 Januari 2015 